\title{
原著 帯脉穴より環跳穴までの文献的考察
}

浜添圆弘

はじめに

帯脉穴より居䆛穴までの部位には, 現代の経穴 学書の殆んどが腸骨の上前側になっている。てれ は霊枢骨 度篇の 季脇より髀枢 までの長さに始ま り，後世の諸書は乙の霊枢骨度篇に従ったもので この季脇より髀枢までの長さの誤りにより，その まま取穴したものと考えられる。以上の誤りの部 について文献的に考察する。

\section{本 論}

一 霊枢骨度篇について

1 霊枢骨度篇の特長

霊枢骨度篇は人体の各部における長さの基準を 表わす根本となるあのである。その各々は縦・横

・周りと各種の長さがあり, 各部の部位的基準で

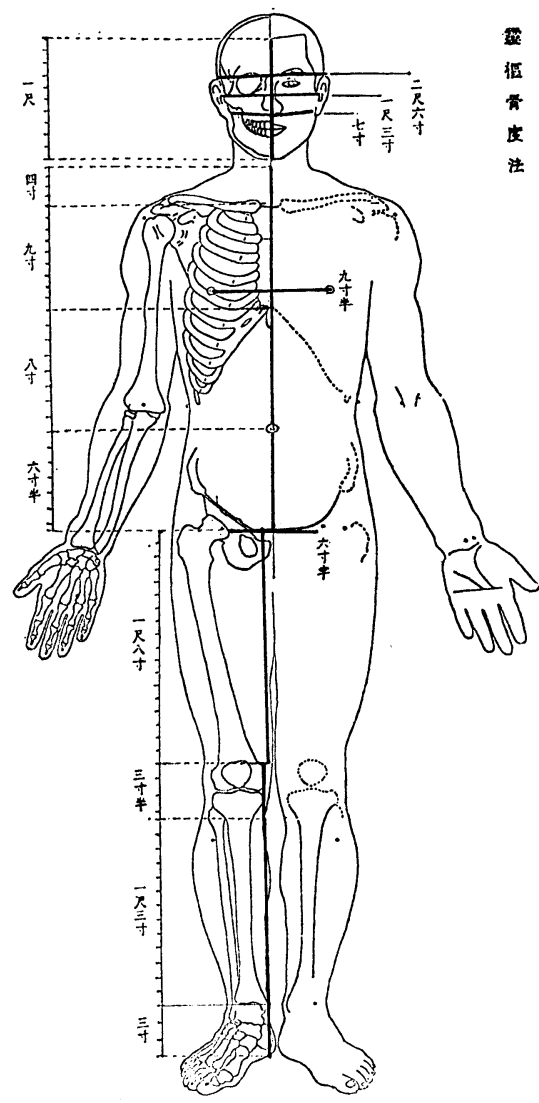

図 1
ある。特に縦の長さの前面と側面は各部位の基準 であるが，総合的に全体を見ると，人体の身長を 表わすあのである。例えば，中指本節から末端ま での長さ 4 寸半は, 取穴上においては使用しない あのでありながら，骨度篇の中に挙げられている

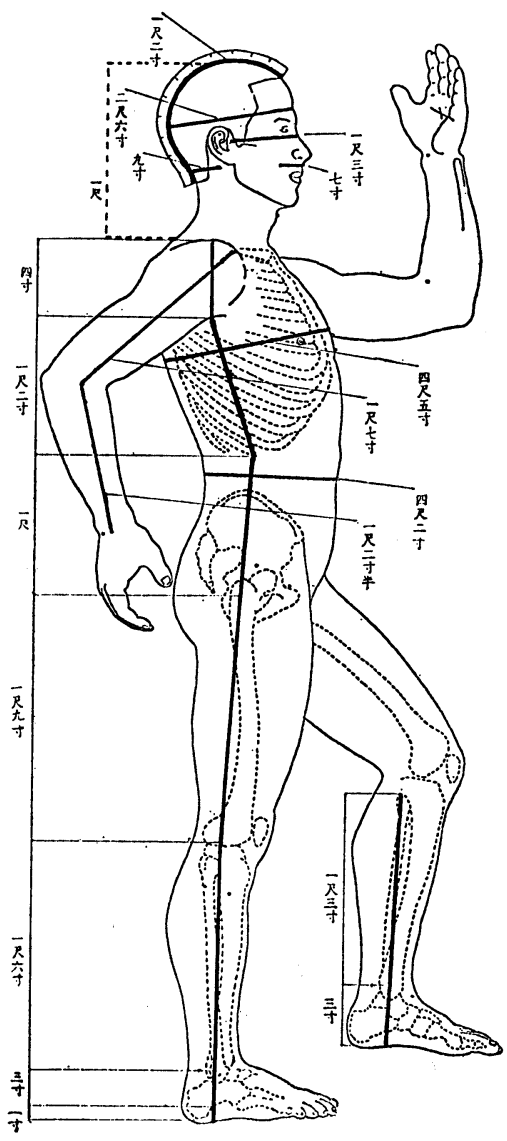

図 2

これは各々その部位の取穴基準だけを表わす目的 ではなく，手は手だけの全体の長さを表わすため のものである。

霊枢骨度篇の各々の長さは，各部における部位 だけの基準でああるが, 全長の中の一部位を表わ すむのである。すなわち総合して各々一連の系統 の全長を表わすあのである。

2 人体の身長を表わす 2 つの系統 
霊枢骨度篇の中で，身体の全長を表わすすのに 次の 2 つの系統がある。

○身体前面の縦の長さの系統

○身体側面の縦の長さの系統

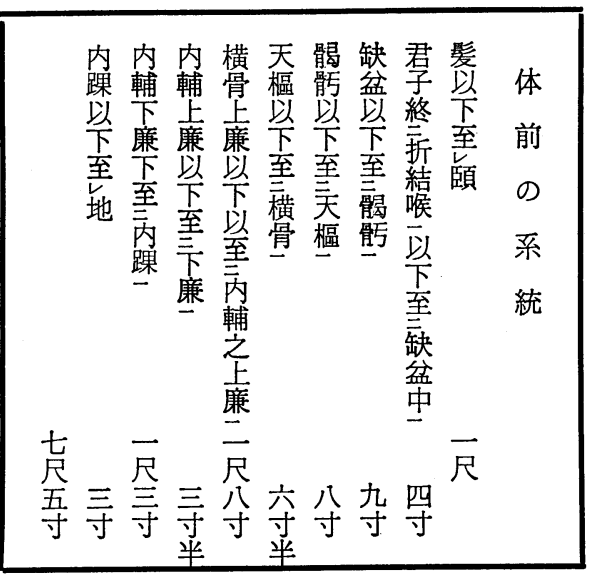

因 3

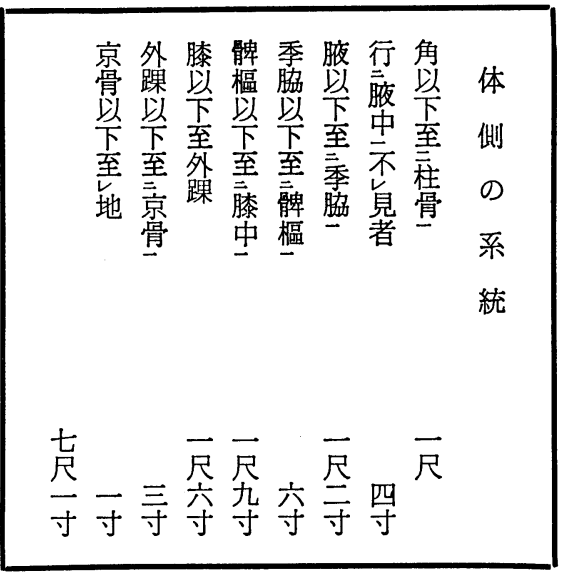

因 4

この 2 つの系統で, 前面は全長 7 尺 5 寸であり 霊枢にいう人の身長 7 尺 5 寸に一致する。側面は 全長 7 尺 1 寸であり，人の身長 7 尺 5 寸より 4 寸 短汃いこの前面と側面の長さは，元来は共に身 長の 7 尺 5 寸に一致したものと推察されるが，ど こかにこの 4 寸の誤差があるべきでさる。

3 骨度篇側面における長さの誤りの部位

a 季脇より上部と下部のバランス

身体側面の縦の長さの系統で, 特に季脇より髀 枢までの 6 寸は，腋以下季脇までの 1 尺 2 寸に対 照すると，半分に当るべき長さが，実測上では半 分より遙かに長い。との季脇より髀枢までの 6寸 の部が，誤差のある部であると考えられる。

$\mathrm{b}$ 古書の指摘（鍼尒説約）
鍼尒説約に「季脇以下至二髀枢－長六寸・髀枢者 環跳穴・按“此一言六寸恐””有レ5゙誤」とある。霊 枢にいう 6 寸の説の誤りの部を指摘している。

二 季脇以下髀枢の基準点

この部の長さの基準点となった季脇と髀枢の解 釈は種々あるが，先づその語句により解釈する。

1 季 脇

（）季は，Mレ子从二稚声一・稚・幼・少・小・末 ・末子・終・細・時節（一くぎり）等の意であ る。

○脇は, 説文に, 叒両膀也M肉劦声とある。通 俗文に，腋下謂之脅・身之左右両膀也之ある。又 わき等の意である。

季は末で下端，脇はわきで側胸部，したがって 季脇は㑡胸部の胸廓下端である。すなわち章門穴 部である。

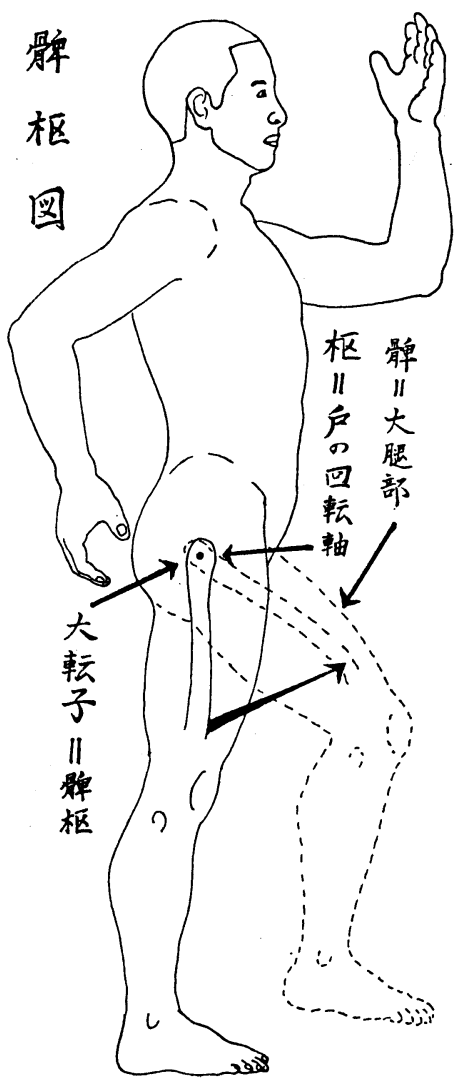

図 5

\section{2 髀 枢}

○髀は，説文に髀股外也从上骨早声とある。髀 早也レ在下称也・脾に通ず・もむ・そともも・股 の外側等の意である。 
○枢は, 戸の回転軸・要・本・中央・大事を司 るむの・重要な・始，等の意である。

髀は股の外側で大腿部, 枢は戸の回転軸, した がって大腿部の回転軸に当る所，すなわち大転子 である。

髀枢は生体の外部より手で探り，一連の長さの 基準点となる部であり, 体部と下肢との境界で, 目標とするにすぐに分かり易い部である。髀枢を 一名髀曰とあいうと解釈したものああるが，髀臼 は寛骨臼のことで, 外部より手で探ることは出来 ない。したがって一連の長さの基準点として外部 より手で探り，大きな目標として用いられたもの ではない。

\section{三 季脇至髀枢の長さ}

1 古書の長さ

a 十四経発揮和語鈔

「按二骨度ノ寸法八季脇ヨリ髀枢マデノ長サ六 寸タリ」とある。甲乙経を始め殆んどの書にある あので, 霊枢にいう6寸の説である。

\section{b 鍼尒説約}

「按此言六寸恐有誤蓋章門季脇下居髎章門下八 寸三分環跳居髎下一寸合得九寸三分挨居答環跳穴 者冝用中指同身寸」とある。章門穴より環跳穴ま でを 9 寸 3 分に取穴している。

\section{c 遂穴啓蒙}

「章門至環跳九寸」とある。章門穴より環跳穴 までを 9 寸に取穴している。

霊枢は髀枢までを 6 寸としてある。鍼炎説約は 環跳穴までを 9 寸 3 分としてある。遂穴啓蒙は 9
寸である。季脇〜髀枢間実測表

\begin{tabular}{|l|c|c|c|}
\hline & 最 長 & 最 短 & 平 均 \\
\hline 実測 $(\mathrm{cm})$ & 27.0 & 18.5 & 21.81 \\
\hline 換算 (寸) & 11.9 & 7.9 & 9.73 \\
\hline
\end{tabular}

困 630 例の実測

下段は身長 7 尺 5 寸に換算したものである。

\section{2 章門穴より大転子までの実測}

章門穴より大転子までの長さを，30名を実測し た結果では，霊枢にいう身長 7 尺 5 寸に換算して 見ると, 最長 1 尺 1 寸 9 分, 最短 7 寸 9 分, 平均 9 寸 7 分 3 厘であった。

人の身長 7 尺 5 寸に一致する前面の 系統に対 し，側面の系統 7 尺 1 寸で 4 寸の誤差は，章門穴 より大転子までの部の 6 寸を 1 尺とすると，腋以 下至髀枢長 1 尺 2 寸とのバランスがとれ，私の実 測とむほぼ合致し，人の身長 7 尺 5 寸に一致す る。髀枢は大転子のととで章門穴から 1 尺であ る。

\section{四 環跳穴の部位}

環跳穴は，大転子と上前腸骨梀の中央の後 1 寸 で，膝を胸に付けると，上前腸骨棘と大転子の間 で中算筋が折れ曲がり，環の様に円くなった所の 中央で, 折り曲げて出来る横紋の尖端にある。大 転子の上前側で，大転子頂点の上 1 寸位の高さに 当る。

\section{五 章門穴より環跳穴までの長さ}

環跳穴は, 大転子と上前腸骨棘との中央の後 1
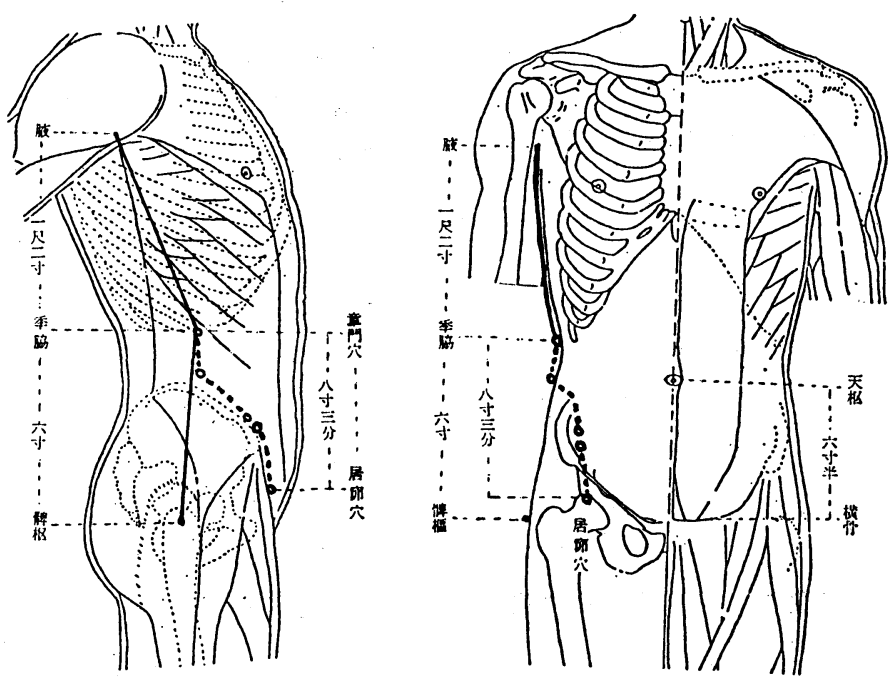


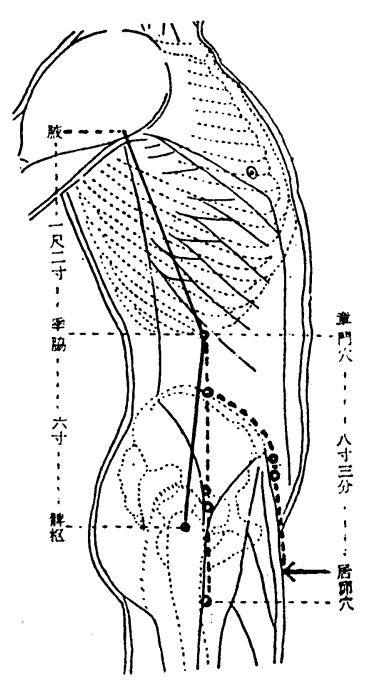

図 8

寸で, 大転子の上前側に当り, 大転子より約 1 寸 位上部の高い部位にある。この部の長さは，章門 穴より大転子頂点までが基準であり，ての寸を以 て環跳穴までを遂穴啓蒙の 9 寸として取穴する。 鍼尒説約の 9 寸 3 分の説は, 大転子に近くなり環 跳穴の位置に一致しなくなる。

章門穴より環跳穴までの長さは，季脇を章門穴 髀枢を大転子頂点と定め, 章門穴より大転子頂点 までを 1 尺とし，取穴上において章門穴より環跳 穴までを 9 寸とする。

六 帯脉穴より環跳穴までの取穴

\section{1 十四経発揮和語鈔}

「按二骨度ノ寸法八季助ヨリ髀枢マデノ長サ六 寸タリ然二居䆛八章門ノ下八寸三分ナレハ六寸ノ 寸 以テ八寸三分二取ヶ時八此穴髀陽 二下テ 側胸 ノ穴二非ス故二張氏力類経ノ四翼二右ノ四穴 $\ni$ 以 テ次第二斜二取之斜ナル時八八寸三分卜雖脇部 ニアリテ髀ニ過ラス乃チ下ノ四ヨ以テ知ベシ」と ある。

章門穴より居窌穴までを上から， 1 寸 8 分・ 3 寸・ 5 分・ 3 寸の 8 寸 3 分として，章門穴より環 跳穴部を目標に直降すると，居莭穴は環跳穴を 通過し, 大転子頂点の下方で大腿部に, 季脇髀枢 間 6 寸の長さで 2 寸 3 分, 同じ季脇髀枢間 1 尺の 長さで 3 寸 8 分 3 厘下る。乙れでは側胸部の穴で はなくなる。それで類経図翼の様に次第に斜に取 れば，体の外側にあり大腿部には下らないとして いる。それで腸骨の上部より前内側の下腹部外縁

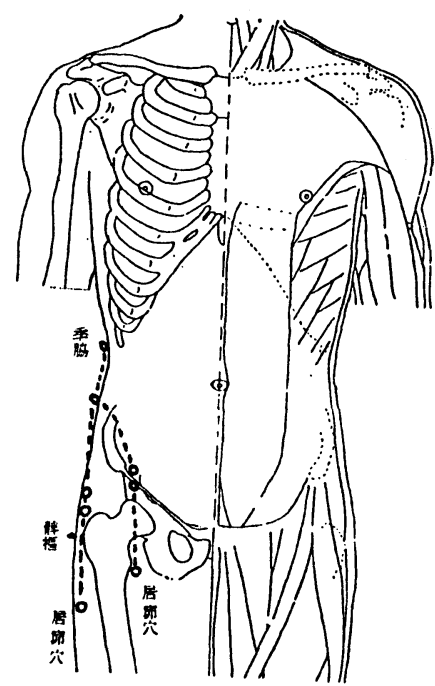

に下る取穴となったものと考えられる。

季脇より髀枢まで 6 寸を基準とした長さで，章 阴穴の下 1 寸 8 分に帯脉穴を取り, 腸骨の上前側 を下行して取穴した場合, 居䠉穴は腹部を通過し て, 大腿部の前内側にある陰廉穴五里穴のあたり まで下行する。とれは季脇より髀枢までの長さが 6 寸でない事を表わすあのである。

又, 古書の取穴図及び現在の 経穴学書を見る と，居䗆穴は府舎穴あたりに取穴しているが，季 脇より髀枢までの6寸を基準にした長さではな く，下腹部の縦寸の 6 寸 5 分を基準にした長さで 取穴した場合の部位である。その穴の部位を対象 にした取穴の基準となる長さがあるのに，下腹部 の長さを基準にして取穴している。

十四経発揮和語鈔は, 季脇より髀枢までは霊枢 骨度篇の 6 寸であるとしながら，他部の違った基 準の長さを当はめた，窮余の策の取穴である。

\section{2 鍼炎説約}

銊尒説約は，章門穴より居穷穴までは同じく 8 寸 3 分とし，環跳穴は居窃穴の下 1 寸として，章 門穴より環跳穴までを 9 寸 3 分として一直線上に 取穴している。

章門穴より環跳穴まで 9 寸 3 分とすると，大転 子の上 7 分に当り, 環跳穴が下に下がり過ぎ，環 跳穴の位置に合わなくなる。

\section{3 遂穴啓蒙}

遂穴啓蒙は，前と同じく章門穴より居䆛穴まで を 8 寸 3 分とし, 環跳穴は居䆛穴の下 7 分で, 章 


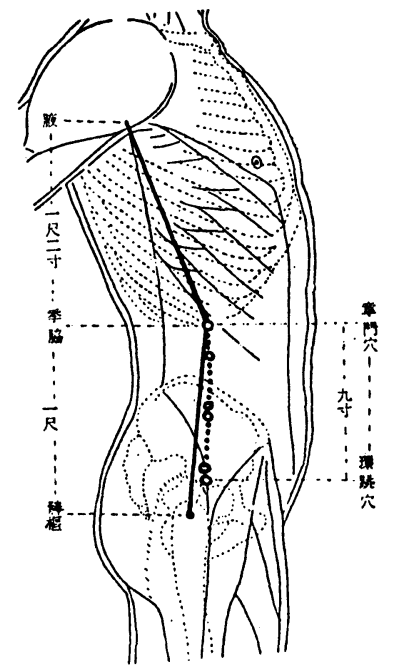

図 9

門穴より環跳穴までを 9 寸として，一直線上に取 穴している。大転子に対する環跳穴の位置，この 部を取穴する基準となる長さにおいてす，最す適 した取穴と考えられる。

以上 3 つの説があるが, 十四経発揮和語鈔は, その穴の基準となる長さがあるのに, 他部の違っ た基準の長さを当てた笨余の策の取穴である。季 脇髀枢間は 6 寸ではない事は明らかである。

銊尒説約は，章門穴より環跳穴まで 9 寸 3 分之 して一直線に上取穴しているが，環跳穴は大転子 に近くなり，環跳穴の位置が合わなくなる。

遂穴啓蒙は，大転子に対する環跳穴の位置，又 取穴基準の長さにおいても，最も適した取穴と考 えられる。

\section{考 察}

霊枢骨度篇は各部の長さの基準であるが, 又一 連の長さを表わすすのである。前面と側面の系統 は身長を表わす。前面は身長の 7 尺 5 寸に一致す るが, 側面は 7 尺 1 寸で 4 寸短かい。側面の系統 の中で, 季脇の上部と下部のバランスが取れない し，鍼众説約もこの部を指摘している。ての部が 間違いの部と考えられる。との部の長さを表わす 骨度篇の基準点である季脇は章門穴，髀枢は戸の 回転軸で大転子である。乙の部の長さは, 霊枢の 6 寸と, 季脇環跳穴間の 9 寸 3 分・ 9 寸の 3 説あ るが，章門穴から大転子までの私の実測30名の平 均では 1 尺であった。この部の長さを 1 尺とする と側面の総計 7 尺 5 寸で, 身長の 7 尺 5 寸に一致

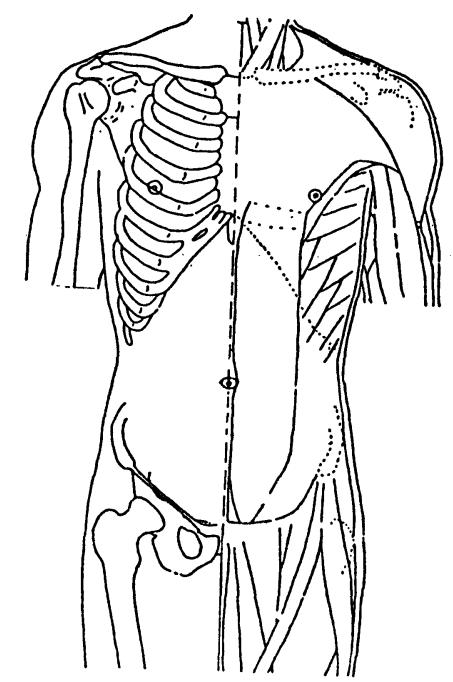

する。

十四経発揮和語は, 骨度篇の 6 寸に従い下腹外 側に取穴しているが，ての6寸の長さではなく他 の部の長さを当てている，窮余の一策の取穴であ

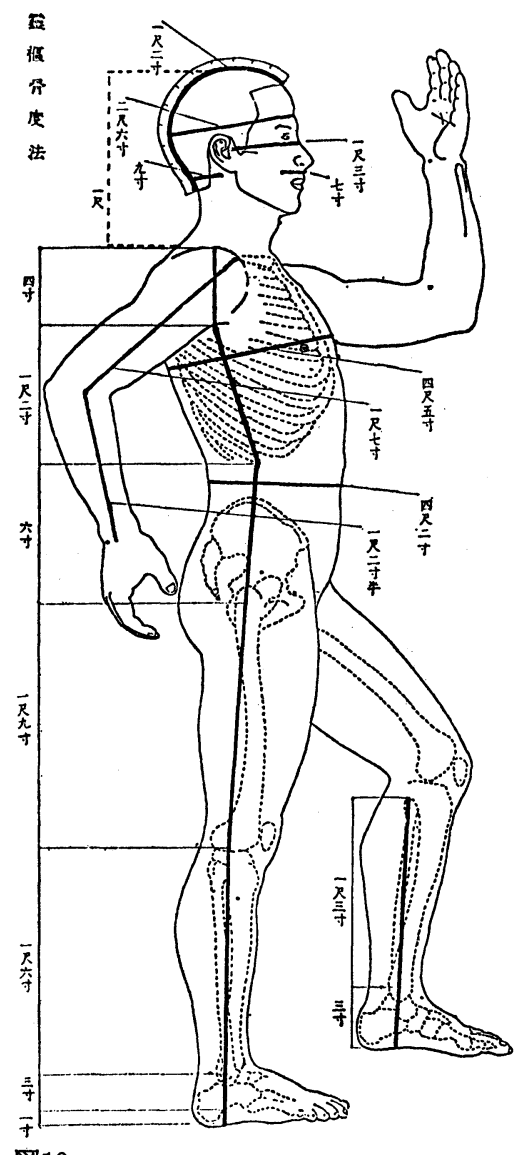

田10 
る。鍼尒説約も環跳穴の部位が違う。遂穴啓蒙の 章門穴から環跳穴までを 9 寸とし，一直線上に取 穴するのが穴の部位・長さ等においてす一致する 取穴法と考えられる。

結 論

（困10）季脇は章門穴部，髀枢は大転子頂点と
し，ての間を 1 尺とする。取穴上において章門穴 環跳穴間を 9 寸とし，一直線上に取穴する。

霊枢骨度篇の季脇より髀枢までの長きこと 6 寸 は誤まりである。

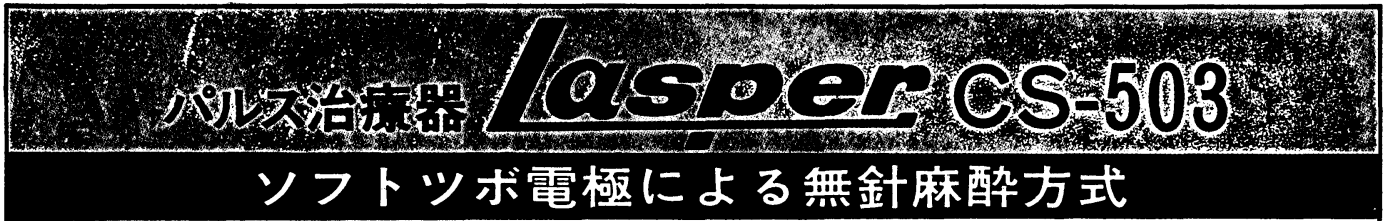

OCS-503は小型ですが大きなパワーをもっています。

OCs-503は中国製の電麻器数種から方の波形を研 究した結果、効果的に作り上げられた双方向性バ

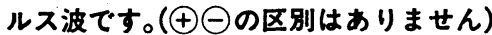

○CS-503は 1 床 1 台をテーマに設㖕された堅审無比 な医療器です。

OCS-503は 1 台で3つの治廉方法があります。

ソフトッボ雪枉とは

○ソフトッボ電極は直径13ミリの半円状の導電体の ゴム製です。これを接着テープによって皮虐に貼 り付け、上から強く押し込み圧痛点をとらえ通電 します。

○ソフトッホ電極を用い、3 $\mathrm{Hz}$ にて20 30分の通 電で麻醉菌を 1 滴も使わずに多数歯抜歯を行って いる歯科医もおります。

発疓元

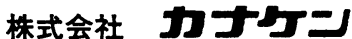

テ227 横浜市緑区美しが丘2-17-39 TEL. 045-901-5471

\section{CS-503の3つの使い方}

1. ハリを用いる方法 通常のパルス治療と針麻酔として使用できる。 疼痛治療に除痛速効性、針麻酔がかかりやすい。

2. ソフトツボ電極を用いる方法

いわゆる無針麻酔方式で、小胃、ご謧人、顔面、 針に恐怖感を持つ患者などに总ばれる、針とほ ぼ同程度の效果が期待できる。

3. 導電スポンジを用いる方法 通常の低周波治㙩のほかに機能荆練（筋運動） などに効果的な応用ができます。

リハビリテーション分野における利用範进が広い。 カパンタイプ、重さ1.3kg、2 エレメント、乾電池使用、

紫造元

三共蒠子工業株式会社 